\title{
El pensamiento político de Macanaz
}

\author{
Rosa M. a Alabrús Iglésies \\ UNED, Barcelona \\ The political thought of Macanaz
}

\begin{abstract}
RESUMEN ABSTRACT
Este artículo analiza el pensamiento político de Macanaz a partir de un texto autobiográfico que se custodia en la Biblioteca Nacional de Madrid. Tres aspectos quedan reflejados: la actitud contra la Corona de Aragón durante la Guerra de Sucesión y sobre los decretos de Nueva Planta; la visión sobre la política europea de Felipe V; y el regalismo, con el consiguiente enfrentamiento con la Santa Sede y la Inquisición.

PALABRAS CLAVE: Macanaz / Nueva Planta / regalismo / siglo XVIII

This article examines Macanaz's political thought from an autobiographical writing located in the National Library of Madrid. Three aspects are considered: the attitude against the Crown of Aragon during the War of Succession and about the New Plant decrees; the vision on the European policy of Philip $V$ of Spain; and the regalism, with the consequent confrontation with the Holy See and the Inquisition.

KEYWORDS:

Macanaz / New Plant decrees / regalism / 18th Century
\end{abstract}

Melchor Rafael Macanaz es un perdedor político arquetípico cuyo perfil biográfico conocemos bien gracias a la obra de Carmen Martín Gaite. Nació en Hellín (Murcia) en 1680, en el seno de una familia de clase media. Su padre y su abuelo ostentaron los títulos de regidores perpetuos de la ciudad. Cursó humanidades en Valencia y fue a Salamanca a estudiar Derecho. Luego ingresó en la corte de Carlos II para efectuar las consiguientes prácticas jurídicas. La presunta ascendencia judía, por parte de madre, motivó la acusación por la Inquisición de cristiano nuevo al padre, que incluso, durante un tiempo, fue privado de su cargo. Nos dice Martín Gaite que el proceder del Santo Oficio en esta cuestión, así como su estancia en Salamanca, donde conoció a los hijos de las principales familias nobiliarias de 
la época (a los que el joven Macanaz eclipsaba con su talento y gran capacidad de trabajo), le marcaron para siempre ${ }^{1}$.

En la corte conoció al marqués de Villena del cual fue un gran admirador. De él se imbuyó del espíritu ilustrado, del gusto por lo francés y de la afición por la lectura y las bibliotecas. Frecuentó también al sector español profrancés, especialmente al duque de Montalto y al cardenal Portocarrero (emparentado con los Villena), con cuyo sobrino estuvo implicado, en Francia, en la conspiración de Cellamare contra el duque regente de Orléans. Sabida es la actitud de Portocarrero, reformista y modernizadora y desde luego, ambigua entre el austracismo y el borbonismo. Con la remodelación del Consejo de Estado (1699), entre otras cosas, éste creía poder remontar el «infeliz estado de cosas» en que se hallaba sumido el decadente reinado de Carlos II. A todos sus incondicionales los situó en lugares clave de la política (al duque de Montalto, Monterrey, al marqués de Leganés, al conde Frigiliana, Antonio Ubilla...). En el futuro no todos serían borbónicos, puesto que el de Leganés fue un reconocido austracista durante la Guerra de Sucesión. En cambio, Portocarrero desplazó a Tomás Enríquez de Cabrera (que luchó con los austracistas en la guerra), a pesar de los intentos de éste de aproximación hacia el embajador francés Harcourt, y en contraste, a algún borbónico como el conde de Aguilar. También Portocarrero dio entrada en el gobierno a muchos filofranceses, siguiendo un criterio pragmático en relación a la política imperialista de Luis XIV y buscando conseguir, al mismo tiempo, un equilibrio entre España, Francia y Austria. Su relación con Harcourt fue decisiva en ese sentido. Portocarrero apoyó la candidatura de Felipe de Anjou como rey de España tras la muerte de Carlos II (1700), pero con la voluntad de conservar la estructura político-administrativa de la monarquía de los Austrias².

Poco a poco, Macanaz, dentro de esas élites cortesanas, estableció contactos muy estrechos con los franceses que rodeaban a Felipe $V$ a principios de su reinado. Es el caso de Ana María de Trémouille (consejera íntima de la reina María Luisa). El segundo marido de ésta (el príncipe Flavio degli Orsini) la presentó al cardenal Portocarrero. Al principio, la Orsini y Portocarrero sintonizaron, pero con el tiempo el cardenal no se identificó con el proyecto uniformista de la francesa. Macanaz a través de ella se relacionó con Orry (enviado por Luís XIV para organizar las finanzas) y con Amelot (discípulo del francés Talon). Participó de la política de éste orientada a contrarrestar el protagonismo de los Grandes de España en el Consejo de Castilla (de esta época es el nombramiento del ciudadano honrado Francisco Ronquillo como presidente del Consejo y su futuro ennoblecimien-

1 Martín Gaite, C.: Macanaz, otro paciente de la Inquisición, Madrid, 1975; Kamen, H.: «Melchor de Macanaz and the Foundations of Bourbon Power in Spain» en The English Historical Review, vol. 80, n. ${ }^{\circ}$ 317, (octubre 1965), pp. 699-716.

2 Peña Izquierdo, A. R.: La Casa de Palma. La familia Portocarrero en el gobierno de la Monarquía Hispánica (1665-1700), Córdoba, 2004, pp. 296-299 y 376-378; RIBOT, L.: El arte de gobernar. Estudios sobre la España de los Austrias, Madrid, 2005, pp. 240-276; GARCíA CÁRCEL, R. y AlABRús IGLÉSIES, R. M.: España en 1700 ¿Austrias o Borbones?, Madrid, 2001, pp. 107-120. 
to - conde de Gramedo - ante el estupor y la disconformidad de la nobleza castellana). Pronto el tándem Amelot-Macanaz consiguió reducir el protagonismo de los Consejos y sustituir el sistema polisinodial de los Austrias por el sistema ministerial a la francesa, primero con dos grandes secretarías de Despacho (Guerra y Hacienda, con Grimaldo al frente, y los demás asuntos con el marqués de Mejorada), modelo que se consolidaría a partir de 1714, tras una fuerte oposición castellana a lo largo de la guerra. Muchos historiadores coinciden en que la Nueva Planta, diseñada para los territorios de la Corona de Aragón, fue en realidad el ensayo que no se había conseguido en Castilla ${ }^{3}$.

De la obra de Macanaz sabemos poca cosa. Está dispersa y sin identificar bien. Durante la restauración canovista, un descendiente suyo, Joaquín Maldonado Macanaz, realizó una breve biografía, como prólogo al escrito jurídico Regalías de los señores reyes de Aragón, publicado en Madrid (1879). También tenemos las referencias de distintos manuscritos de Macanaz que Modesto Lafuente aporta en su Historia de España ${ }^{4}$. Pero el objeto de este artículo es ahondar en su pensamiento político reflejado a modo de confesión autobiográfica en el manuscrito titulado Males, Daños, y Perjuicios que han ocasionado a la España... de la Biblioteca Nacional. Lo finalizó en octubre de 1744. En él hace un recorrido por todos los problemas o «males» de España durante y después de la Guerra de Sucesión, a la vez que justifica sus actuaciones a lo largo de su longeva vida (murió en 1760, a los noventa años) $)^{5}$.

De este texto de Macanaz son especialmente relevantes tres aspectos: su actitud específica en la Guerra de Sucesión frente a la Corona de Aragón con su definida posición ante lo que él creía que tenía que ser la Nueva Planta, precisando al respecto sus diferencias con la obra de Belando; su participación desde el exilio en la política europea de Felipe $V$ después de 1714 como hombre de confianza del rey; y, por último, su pensamiento regalista y su choque con la Iglesia y la Inquisición, con matices que, a mi juicio, no han contemplado los historiadores que han abordado el regalismo de Macanaz.

3 Martínez Shaw, C. y Alfonso Mola, M.: Felipe V, Madrid, 2001, pp. 220-221 y 227-228; Giménez LóPEZ, E.: «La Nueva Planta en la Corona de Aragón», en El cambio dinástico y sus repercusiones en la España del siglo XVIII. Homenaje a L. Coronas Tejada, Jaén, 2000, pp. 31-32; LóPEZ CoRdóN, M.V.: «Instauración dinástica y reformismo administrativo: la implantación del sistema ministerial» en Manuscrits, $\mathrm{n}$. ${ }^{\circ}$ 18 (2000), pp. 93-111; DÉDIEU, J. P.: «Dinastía y elites de poder en el reinado de Felipe V», en FERNÁNdez Albaladejo, P. (ed.), Los Borbones. Dinastía y memoria de nación en la España del siglo XVIII, Madrid, 2001, pp. 390-391; y GARcía CÁRCEL, R..: Felipe $V$ y los españoles, Madrid, 2002, pp. 114-120.

4 Maldonado Macanaz, J.: Regalías de los señores reyes de Aragón, Madrid, 1879; Lafuente, M.: Historia general de España, (siglo XIX), vol XIII, Madrid, 1858.

5 Biblioteca Nacional de Madrid (en adelante BNM), Mss. 2768, Macanaz, M. R. de: Males, daños y perjuicios que han ocasionado a la España, a su Iglesia y a su Rey los extranjeros que han tenido manejo en el Ministerio Español, año 1744. 


\section{EL CONCEPTO DE ESTADO DE MACANAZ}

El texto aludido de Macanz hace constantes referencias a la obra del borbónico alicantino Nicolás Belando: Historia civil de España. Sucessos de la guerra y tratados de paz, desde 1700 a 1733, obra que tuvo problemas con el Santo Oficio, lo que al viejo Macanaz le generaría de entrada una indudable solidaridad con Belando ${ }^{6}$. Pero, al mismo tiempo, Macanaz difiere claramente de la sensibilidad periférica del alicantino. Acusa al cronista alicantino de haber omitido «tantas y tan lastimosas noticias para la España» o bien lo ataca por las «infieles acciones de sus paisanos" y por haber escrito demasiado sobre la resistencia valenciana y la represión hecha por los franceses. Comentarios de Belando como el «aumento de la represión borbónica por las revoluciones de Valencia, Aragón y Cataluña» o haber narrado que el archiduque Carlos, cuando entró en Madrid en 1706, se «comprometía a guardar justicia y a respetar los fueros» no eran compartidos por Macanaz. No entendía la contraposición entre fidelidad castellana y rebeldía de los territorios de la Corona de Aragón. Su condición de seguidor del modelo arbitrista francés se lo impedía.

Ciertamente, Belando rechazaba el arbitrismo francés. De la actuación de Asfeld en Valencia llegó a afirmar que «con él ya el rigor llegó a padecer excesos, pareciendo que era deleite acabar con la vida de los hombres [...] De esta manera se vio hecho escarnio de la fortuna el ameno, fértil y hermoso reino de Valencia llevando tales máximas los vencedores, que parecía no la reservaban para el rey, sino que lo destinaban para mísero despojo de su codicia. Se cometieron tantas tiranías, extorsiones e injusticias que se pudiera llenar un libro y aun formar una larga historia de las vejaciones que padeció todo el reino. Todavía en el día de hoy viven muchos que con las alhajas propias miran adornada la casa ajena; y por la modestia, no declaro aquí los nombres de los que injustamente en aquel tiempo defraudaron las riquezas de este reino; y así mismo callo la grande suma de dinero, que de él se sacó, sin que el menor maravedí sirviera para el rey, sino para dejar manchados a los que con la espada habían ilustrado su nombre [...] A la violenta ambición de la salteadora codicia [...] a las ruinas tempestades se ha añadido la gran nube de piedra de los arbitristas, así naturales, como forasteros, que con el pretexto de hacer servicio al rey, y beneficiar la Real Hacienda, aumentaron sus caudales y acabaron con sus vasallos ${ }^{7}$.

6 Belando, N.: Historia civil de España. Sucessos de la guerra y tratados de paz, desde 1700 a 1733. Los dos primeros volúmenes se publicaron en el año 1733; el tercer volúmen en 1740; LLORENTE, J. A..: Historia general de España, vol. XIV, p. 92. Llorente afirma que en 1717 Felipe $\mathrm{V}$ firmó un decreto condenatorio de la defensa de las regalías hechas por Macanaz. La prohibición de la Historia civil de España... de Belando por la Inquisición se hizo por considerarla apologista de Macanaz; BogLIOLO, E.: Tradizione e innovazione nel pensiero politico di Vicenzo Bacallar, Milano, 1989, pp. 193-194. El autor afirma el protagonismo que Belando otorga al rey en la Historia Civil..., a diferencia de la defensa del constitucionalismo en la Monaquía Hebrea de V. Bacallar; ALABRús IGLÉSIES, R.M.: Escrits polítics del segle XVIII. Cròniques de la Guerra de Successió, vol. IV, Vic, 2006, pp. 12-19.

7 Belando, N., Historia civil..., vol. I, pp. 248-261 y 322 
Macanaz empieza a criticar a Belando por haber citado una obra de Cayetano Cenni (1739), «que no acababa de alabar las reglas y el régimen de la Iglesia de España, ni tenía en cuenta las leyes góticas para el régimen de su vasta monarquía». El goticismo de Macanaz era palpable. Sus fuentes de inspiración histórica y política se encontraban en los «godos que mejoraron el gobierno - contraponiéndolo al de los fenicios, cartagineses y romanos- de tal suerte que el mundo no ha conocido otro mejor, formando sus leyes góticas en un código que llevaba por título Fuero Juzgo del cuál tienen bastante noticia los entendidos, como también del otro código de los Cánones para la Iglesia [...] Después como la España ha padecido tanto por las varias naciones que han contratado su felicidad, los Reyes Católicos fueron separando las mudanzas del gobierno y sin alterar la sustancia de los referidos códigos añadieron leyes y disposiciones según los parajes y circumstancias ocurrentes [...], gobierno que después alteraron los extranjeros que se fueron introduciendo y mezclando en el mando espiritual y temporal [...] desde Felipe I y su hijo Carlos I y V, emperador de Alemania, con sus alemanes y flamencos que sin tocar en lo católico llevaron las cosas al término de sus intereses que les hacían salir de las reglas antiguas e introduciendo leyes nuevas fueron alterando u olvidando los contenidos de los códigos. De manera que los extranjeros que solo vienen a España arrebatados del interés habían alterado las cosas sin haber hecho presente a los soberanos cuanto importa para los vasallos, lo contenido en estos códigos [...] De modo que sin detenerse en la opacidad de las nubes, así como para todos los vasallos es uno rey [...] y que también una ley de su gobierno, acabando con las leyes y gobiernos que hasta aquí han sido fatales, pues no basta la vida de un hombre para leer y menos para examinar tanta multitud de volúmenes que hay hoy escritos de las muchas leyes, fueros, usos, costumbres, ordenanzas, pragmáticas y resoluciones que por la variedad referida ha sido preciso aumentar. Y esto estaba remediado con dar vigor a aquellos dos celebérrimos códigos del Fuero Juzgo y de las leyes de la Iglesia de España, mandando que en las Universidades se leyera y que los Consejos, Chancillerías y Audiencias y demás Juzgados por ellos y por otros se hubieran de gobernar, lo qual no es cosa irregular, pues los Godos con solo el dicho Código de las Leyes Góticas, governaron sus dilatados Estados, que eran las Españas, las Galias, y todo lo que hay de los Alpes a esta parte, con el vasto imperio de los Hunos sin necesitar leyes imperiales»8.

De ello se deduce la fijación de Macanaz por la unidad y el orden que tuvo ocasión de llevar a la práctica en la aplicación de la Nueva Planta en Valencia, conjuntamente con el francés Asfeld, sin duda con demasiado celo. Fue allí donde el murciano ejerció como Juez de Confiscaciones, después de la victoria borbónica de Almansa (1707). Desde la corte se le propuso la reedificación de Xàtiva. Sus resultados no fueron satisfactorios, al quedar la ciudad despoblada no sólo por la carnicería de los franceses, sino también por las medidas drásticas de Macanaz. Muchos borbónicos, como el arzobispo valenciano Folch de Cardona o el cardenal

${ }^{8}$ BNM, Mss 2768, Males ..., fols. 64 a 67 
murciano Belluga, hartos de protestar por el trato vejatorio de Macanaz a los valencianos y por sus intentos de desamortización eclesiástica, se pasaron al bando austracista.

Los otros cronistas borbónicos —López de Mendoza y Pons, conde de Robres; Bacallar, marqués de San Felipe; José Manuel Miñana...- hacen referencia a la represión francesa en Valencia, pero no mencionan el proceder de Macanaz. Desde otros sectores borbónicos, sí que le llovieron muchas críticas al murciano. Así el presidente de la Chancillería de Valencia aseguraba que «D. Melchor de Macanaz interpreta el indulto de su Majestad diciendo que no comprende al distrito de la antigua Játiva, siendo así que la real Clemencia se extendía a todos los que no perseverasen en su obstinación ni se hubiesen pasado a los enemigos, por cuyo motivo se ha cerrado la puerta a muchos que con la esperanza del recobro de sus bienes se acogerían a la ciudad ${ }^{9}$.

En febrero de 1708 Macanaz mandó un resumen de sus pesquisas en Xàtiva a Grimaldo. Había constatado que «de 200 eclesiásticos, solo unos 25 habían sido fieles a Felipe $V$ ». Añadía que por ello había que diezmar al clero. Por tanto su voluntad no sólo era reformar la Iglesia, sino aplicar al clero una medida política, de castigo. El mismo argumento lo volvió a esgrimir después, al final de la Guerra de Sucesión, en Cataluña: «Mi objeto fue siempre que la corte romana asegurase algunos de tantos intereses como indebidamente lleva a los españoles y de modo, que sobre verse las Iglesias de España despojadas de sus Rentas y Provisiones de Beneficios no se viesen también con la intolerable carga que se les ha impuesto de proveer muchas de sus Prebendas y Beneficios en hombres facinerosos, obscuros, ignorantes e indignos que faidos de la política romana [...] se dan desde luego a una vida licenciosa. Se van a Roma y vuelven absueltos de sus irregularidades [...]». Y añade: «También deseé se desterrase el abuso de ser la Iglesia refugio y cueva de ladrones, facinerosos, homicidas y asesinos, que es lo que sin ejemplar se ve en España [...] y el haberse visto durante la guerra pasada tantos escándalos en muchos eclesiásticos de las Provincias y reinos revelados, sin castigo, corrección ni enmienda». Macanaz, desde luego, acentuó su campaña contra el clero en los años 1713-1714, dada la implicación de éste en Cataluña a favor de la causa austracista ${ }^{10}$.

El autor de los Males, Daños y Perjuicios que han ocasionado a la España... hace una verdadera apología del uniformismo político. Para él, el Estado centralizado estaba por encima de todo, valiéndose de métodos dirigistas y dictatoriales para solucionar esos problemas. A partir del Estado y como medida política, se entiende también buena parte de su regalismo y su batalla por mermar la influencia de la Santa Sede. Un contemporáneo suyo francés, el brillante barón de Montes-

9 Alabrús, R.M.: Cròniques de la Guerra..., pp. 43-46; GıMÉNEZ LÓPEZ, E.: Militares en Valencia (1707-1808), Alicante, 1990, p. 24.

10 Martín Gaite, C., Macanaz... p. 125; BNM, Mss 2768, Males ... fols. 78 a 80. 
quieu, reconocía en sus Cartas Persas - un buen testimonio de opinión sobre la Europa de la época - el creciente peso de la Iglesia en la política de Estado de la nación francesa, a principios del siglo XVIII: «Ha abandonado las leyes antiguas que hicieron sus primeros monarcas en las asambleas generales de la nación; y lo singular es que las romanas que en vez de aquéllas han sustituido, fueron parte hechas y parte recopiladas por emperadores coetáneos de sus legisladores [...] Y para que fuese más cabal la ganancia y que les viniese toda la sana razón de fuera, han adoptado todas las constituciones de los Papas, componiendo con ellas una nueva parte de su derecho, que es nuevo género de esclavitud». Sus declaraciones ponen de manifiesto el gran protagonismo papal en estos momentos, pero, a diferencia de Macanaz, Montesquieu defendió un concepto plural del Estado ${ }^{11}$.

¿De qué fuentes bebió el pensamiento de Macanaz? Siguió a diversos regalistas y arbitristas españoles de la época de Felipe III y de Felipe IV, preocupados en estudiar y resolver la precariedad económica y la decadencia de España, «males» que después recuerda Macanaz en su manuscrito, enlazándolos con los del reinado de Felipe V. Se trata de Fernández de Navarrete, el obispo de Córdoba fray Domingo Pimentel o el consejero de Castilla, Juan Chumacero, así como de los arbitristas castellanos Sancho de Moncada, Jerónimo de Ceballos, Frasso, Salgado, González de Salcedo, Solórzano o Larrea. Particular influencia ejerció sobre él la Conservación de monarquías (1626) de Fernández de Navarrete, inspirada en una consulta anterior hecha al Consejo de Castilla (en el reinado de Felipe III) sobre las causas de la decadencia y posibles remedios de la misma, y el Memorial de Chumacero presentado más tarde al Consejo (en el reinado de Felipe IV). Curiosamente, un contemporáneo austracista de Macanaz, Juan Amor de Soria, bebió de las mismas fuentes, particularmente del pensamiento arbitrista castellano de Fernández de Navarrete aunque, en su caso, adobado con el pensamiento constitucionalista de la obra de Saavedra Fajardo. A partir de esas lecturas, Macanaz urdió un conjunto de medidas centralizadoras y regalistas rompiendo con el foralismo de la «monarquía compuesta» de los Austrias. Con el tiempo y ante las trabas que tuvo que lidiar, intentó la conjugación del arbitrismo regalista castellano del siglo XVII con el arbitrismo francés del equipo de la Orsini (inspirado en Barclay y Talon). Se estrenó en Valencia, como Juez de Confiscaciones, lo que le valió las quejas de los valencianos, hasta el punto de que Folch de Cardona llegó a pedir al Papa su excomunión (1709). Macanaz fue hábilmente desplazado por el rey a Aragón. Por recomendación del confesor de Felipe V, el también regalista Robinet, recibió el encargo de administrador en la Junta del Real Erario (1711). Su afán intervencionista, fuera de lugar, le ocasionó constantes agarradas con el mariscal francés Tserclaes de Tilly, presidente de la Junta. A pesar del prestigio del francés, Macanaz tenía en este momento el respaldo absoluto del rey y consideraba que

11 Pujol, C. (ed.): Barón de Montesquieu. Cartas persas, Barcelona, 1989, pp. 157-159 y 166-167; IGLESIAS, C.: El pensamiento de Montesquieu, Madrid, 2005, pp. 497-498. 
éste «resolvió que se estuviesen en sus casas, que nunca más se juntasen y que yo, como intendente general, cuidase de todo»12.

Era un momento delicado. Felipe $\mathrm{V}$ recelaba del duque de Orléans, que había pactado el reparto de la Corona de Aragón con Stanhope en la llamada «trama de Lérida» (1709). En esa inquietante situación de contestación valenciana y aragonesa, de difíciles relaciones de Felipe $\mathrm{V}$ con Luis XIV, de desconfianzas castellanas hacia lo que podía representar la Nueva Planta, Amelot fue sacrificado y retornó a Versalles. La Orsini, Orry y Macanaz siguieron enfrentándose al sector borbónico constitucionalista castellano que integraban además de Francisco Ronquillo, el presidente del Consejo de Castilla, el marqués de Bedmar, el duque de Medinasidonia y el de Montellano y el conde de Frigiliana, entre otros. El propio San Felipe calificaba a Orry de despótico y opinaba así del gobierno de Felipe V en 1713: «Faltaba aquella armonía que ha de menester el gobierno y más cuando lo más reservado de él se fiaba solo a la princesa de Orsini». Paralelamente se acentuaron las discrepancias entre los propios franceses (entre el duque de Pópuli y Orry hubo un conflicto constante desde septiembre de 1713) ${ }^{13}$.

En enero de 1713 se le pidió a Macanaz que hiciese un informe sobre Cataluña, ya que los borbónicos creían inminente la caída del Principado antes de la firma de la Paz de Utrecht en marzo. En esa memoria, fundamentalmente política, Macanaz decía a Felipe $\mathrm{V}$ que por la rebelión de los catalanes «sus fueros y privilegios quedan derogados, y no hay más ley, fuero ni privilegio que la voluntad del rey [...] Todas las Juntas del Principado quedan incorporadas al Real Patrimonio [...] así como los privilegios particulares de las comunidades en ciudades, villas y lugares. Las dignidades y títulos (duques, condes...) a la Corona. Todos los oficios de Justicia, Policía, o sean militares del Principado a disposición de SM. Todos los estados, rentas y preeminencias de mayorazgos quedan extintos y los privilegios y bienes incorporados al Real Patrimonio [...]». Y añadía: «Convendrá, cuando se haya de regir en aquel Principado, igualarlo lo más que se pueda en todo a los reinos de Aragón y Valencia, y bajo las mismas reglas que para esto se han notado».

La resistencia de los catalanes a quedar sometidos a las «leyes de Castilla» está muy presente en 1713-1714. Así se pone de manifiesto en el texto austracis-

12 BARCLAY, J.: Pietas sive publicae pro regibus ac principibus \& private pro Guillermo Barclaio parente vindicta adversum Roberti S.R.E. Cardinale Belarmini Tractatum de Potestate summi Pontificis in rebus temporalibus, 1640, citado en el manuscrito de Macanaz, BNM, Mss 2768, Males ..., fol. 38; KAMEN y MARTín GaITE afirman que se publicó en 1642; TALON, O.: Traité de l'autorité des rois touchant l'administration de l'Eglise, Amsterdam, 1700; MARTín Gaite, C., Macanaz... pp.37-38 y 257; ABELLÁN, J. L.: «Del Barroco a la llustración (siglos XVII y XVIII)» en Historia Crítica del Pensamiento español, vol III, pp. 303 y 310-322; JoveR, J.M.a: 1635. Historia de una polémica y semblanza de una generación, Madrid, 2003, pp. 401-402; LLUCH, E.: La Catalunya vençuda del segle XVIII. Foscors i clarors de la II.lustració, Barcelona, 1996, pp. 82-88.

13 Belando, N. Historia civil..., vol I, pp. 405-407; BacallaR, V. (marqués de San Felipe): Comentarios de la guerra de España e historia del rey Felipe V, el animoso, Edición e introducción de C. SECo, Madrid, 1957, pp. LIX, LXI, LXVII y p. 266; BNM, Mss. 12173, BACALLAR, V.: Comentarios de la guerra de España, libros 12-16, años 1712-1726, fol. 19 
ta de la Lealtad Catalana (1714): «Lo que sobre esto debe estrañarse de los generosos genios de los castellanos, es que porque tienen ellos tan mala vida, quieran que todos padezcan. Si reduciendo la Corona de Aragón a las leyes de Castilla habían de conseguir ellos las libertades de aquella, tendrían disculpa; pero si el hacer a ésta esclava no les alivia la cadena que ellos arrastran, antes si bien lo consideran les aumenta eslabones, ¿qué interés podrían sacar de conseguirlo?». La castellanización, desde luego, no era compartida por todos los borbónicos. El conde de Robres, después de la batalla de Almansa y de la derogación de los fueros en Valencia, había dicho: «Es cierto que en Castilla han estado siempre malhumorados con nuestras prácticas y exenciones y recelo que la oposición de la idea de extirparlas ahora en algunos próceres pudiese proceder de que se les acababa el honroso empleo de virreyes, debiéndoles sustituir los corregidores para univocar el gobierno con Castilla [...] todos los castellanos desearon tanto su ruina, que he oido el que la promesa que de ella se hizo a los pueblos les mantuvo el año 1706 fieles al señor Felipe $V$, más aún que su misma obligación y amor ${ }^{14}$.

En abril de 1713 se le encargó a Macanaz la redacción de las Instrucciones sobre la evacuación de Cataluña para el general que hubiese de ir: «El cuerpo de la ciudad —refiriéndose al gobierno de Barcelona- que es ahora más preciso que otro alguno, lo compondrá de algunos buenos sujetos notoriamente leales, y lo mismo será de las demás ciudades, villas y lugares del principado. La Diputación del Principado ni es necesaria, ni consentiré que se junte». A lo largo de todo este tiempo Macanaz había aconsejado a Felipe V dureza en Cataluña: «Nunca ha habido en España más necesidad de crear nuevas, grandes y nobles familias que en el tiempo presente, pues de once millones de vasallos que se numeraban antes de la guerra, no llegan hoy a ocho; la nobleza en la mayor parte se perdió o cayó del todo; las letras se olvidaron; los tribunales todos deliraron y ha venido todo al miserable estado que la experiencia nos demuestra» ${ }^{15}$.

Después de la muerte de la reina María Luisa, a principios de 1714, Felipe V, aquejado de depresión, dejó los asuntos de gobierno en manos de Grimaldo (secretario de despacho), del cardenal Giudice (consejero e inquisidor general) y de la princesa de Orsini. Fue entonces cuando ésta destituyó a Ronquillo de la presidencia del Consejo de Castilla. Con sus otros dos colaboradores -Orry y Macanaz- reformó el Consejo creando cinco presidencias, depurando consejeros y añadiendo en él a sus hombres de confianza: el marqués de Jamaica, el duque de Veragua y el príncipe de Cellamare... A lo largo de este año se concretó el sistema

14 SANPere y Miquel, S.: Fin de la Nación Catalana, Barcelona, 1905, p. 29; BC (Biblioteca de Catalana), F. Bonsoms, n. ${ }^{\circ} 703$, Lealtad Catalana Purificada de invidiosas calumnias entre llamas de sufrimientos en el Crisol de la Constancia Esmaltada con lo heroyco de la Resolución de defenderse Cataluña por el Rey y por la Patria, Vilafranca, agosto 1714, pp. 35-45; AlABRús, R.M.: Felipe V i l'opinió dels catalans, Lleida, 2001, pp. 307-310; LóPEZ DE MENDOZA y PONS, A. (conde de Robres): Historia de las guerras civiles, Zaragoza, 1882, pp. 365-366.

15 SANPERE y MiQuel, S.: Fin de la Nación..., p. 74. Sanpere cita a Maldonado Macanaz y su obra Regalías de los señores reyes de Aragón, pp. 205-206. 
ministerial a la francesa con cuatro secretarías. Además Orry y la Orsini quisieron nombrar al marqués de Villena como condestable del rey. Las excusas que la Orsini dio al Consejo fueron que Ronquillo hablaba mal del gobierno y que se había juntado con el marqués de Brancas con fama de «malgastador y dado a la buena vida». Brancas era el embajador de Francia en España. De hecho, actuó como un espía al servicio de Luis XIV, informando puntualmente a Versalles de la inestable situación de la corte de Madrid. Luis XIV pretendía averiguar de donde venía la obstinación de Felipe $V$ en relación a los catalanes, a partir de las quejas de Tessé (que ya en 1706, después del fracasado sitio de Barcelona, había aconsejado a Felipe que volviera a Francia).

Felipe $\mathrm{V}$ y la Orsini, desestabilizados, decidieron pactar con el cardenal Giudice que fuera a París, a principios de 1714, para contrarrestar la información del agente francés que había dicho en Versalles que «la corte de España hacía punto de honor de sostener la pretensión de erigir en Flandes un principado de 30.000 ducados de renta a favor de la princesa de Orsini». Luis XIV decidió enviar a Berwick a Madrid con la excusa de dar el pésame a su nieto por la muerte de la reina. Una vez en Madrid, Berwick y Ronquillo intrigaron contra la Orsini. Ambos la consideraban como «la tirana de la España y perjudicial a la Francia». Ésta se quejó ante Felipe de que Berwick estaba allí porque Luis XIV se negaba a reconocer las promesas hechas, sobre un territorio en Flandes, del rey español para ella. Entre la llegada de Berwick y las negociaciones de Rastadt (primavera de 1714) parece que Luis XIV exigió de forma inmediata a Felipe que se aviniera a las negociaciones con los catalanes, o de lo contrario le retiraría la ayuda: «no quería por un particular interés de la princesa dilatar la Paz en sus reinos y empeñarlos en nuevos gastos». En julio de 1714, volvía a escribir a su nieto: «Estoy muy lejos de proponeros que les devolváis sus privilegios pero concededles -a los catalanes- su vida y todos los bienes que les pertenezcan, tratadles como a súbditos a los cuáles estais obligados a conservar [...] y no debéis destruir» ${ }^{16}$.

Hay un antes y después de este ultimátum. Los criterios extremistas de Macanaz cayeron, poco a poco, en desgracia. Después del once de septiembre de 1714 se disolvieron a la fuerza las instituciones políticas catalanas (Generalitat, Consejo de Ciento y Brazo Militar) y fueron sustituidas por la Real Junta de Administradores, que desde finales de 1714 actuó de forma represiva (ejecuciones, deportaciones...), militarizando el Principado. Paralelamente Macanaz pretendía «discurrir el modo efectivo y eficaz para contener, castigar y aun limpiar el Principado de todos los clérigos y frailes manifiestamente conocidos por malos y rebeldes». Frente a esta actitud el felipista conde de Montemar aconsejaba a Felipe:

16 BNM, Mss 12173, BACALlaR, V.: Comentarios de la guerra..., fols. 31, 35-37, 41 y 57-59; BACALLAR, V.:, Comentarios..., p. 60. Bacallar asegura que el marqués de Villena era un inepto como gobernante y que no contaba con el respaldo de la nobleza; Boglıolo, E.: Tradizione e innovazione..., p. 34; ALABRús, R.M.: Cròniques de la Guerra..., pp. 42-43; CASTELlví, F. de: Narraciones históricas, Madrid, 2002, vol. IV, p. 23. 
«ahora es cuando SM podrá establecer en el Principado la forma de gobierno que fuese conveniente a la satisfacción de su justicia» y «parece que en el establecimiento que VM resolviese será peligroso el rigor si no se consulta con los afectos del Pueblo, con quién obra más la destreza que el Poder, y más el exemplo que la severidad». Ante la obsesión de Macanaz no sólo con la uniformización, sino con la castellanización de los regidores municipales se optó por darle al flamenco Bergeyck el arbitrio del derecho civil catalán, que se mantuvo. Junto con el pragmático Patiño y algunos juristas borbónicos catalanes como Francesc d'Ametller o Josep d'Alós i Ferrer, articularon un diseño más posibilista de la Nueva Planta (1716), aunque la representación y la elección en los municipios catalanes se sustituyera por el modelo castellano y la lengua castellana se impusiera para las causas de la Real Audiencia. Políticamente Macanaz ya no tenía nada que hacer. Desde entonces odió a Patiño. Le parecía que por su actuación la «rebelión» persistía en Cataluña, todavía, después de la Guerra de Sucesión ${ }^{17}$.

Patiño, como Intendente de Cataluña, opinaba que «por lo tocante a negocios civiles e intereses de partes, no se hallaba el menor perjuicio al Estado y a la autoridad real, y a las regalías soberanas", permitiendo - tal y como nos dice J. Mercader i Riba - que el Derecho catalán «se observase en todo género de últimas voluntades y contratos", de modo que si se introducía una legislación desconocida - pensaba - podía crearse confusión y desórdenes. Ametller era más dogmático: «pues cuanto se mantenga y revalide de la legislación y usos antecedentes de ese Principado, que no lo contemplen sus comunes y particulares como cosa pretérita, ni se les conceda ahora para que gocen de los privilegios y exclusiones de antes, ni se valgan de los mismos preceptos sino en virtud de nueva Pragmática y en tanto perdure el Real beneplácito, pudiendo sin obstáculo mudarlas y derogarlas el soberano, siempre que lo juzgue como útil y conveniente al bien común». Por lo que respecta al tema eclesiástico Patiño opinaba que «quitar la jurisdicción criminal a los barones eclesiásticos y aplicarla los corregidores es de grave inconveniente y rozaría la inmunidad de su fuero". Ametller era más regalista pero se avino, aparentemente, a no topar con la inmunidad de la Iglesia. Entre estas posiciones enfrentadas, el borbónico catalán Josep d'Alós i Ferrer se caracterizaba por la ambigüedad. Había tenido que exiliarse en 1705, al proclamarse Barcelona a favor del Archiduque. A su retorno (1712), colaboró abiertamente con Pópuli y Grimaldo, ejerciendo el espionaje y desarrollando diversos cargos en la administración felipista. Pero los borbónicos lo acusaban de haber simpatizado antes con la causa austracista. Parece ser que en 1705, Alós, no se pasó al bando borbónico hasta el último momento, cosa que le reprochaban. Además el informe que realizó en 1715, donde preveía el posible retorno de las tropas del archiduque Carlos en Bar-

17 Albareda Salvadó, J.: La Guerra de Successió i l'Onze de Setembre, Barcelona, 2000, pp. 113144; ToRRAs RibÉ, J.M.: Felipe V contra Catalunya, Romanyà Valls, 2005, pp. 46, 86, 161 y 166; GIMÉNEZ LÓPEZ, E.: «El primer capitán general de Cataluña, marqués de Castelrodrigo (1715-1721) y el control del austracismo», en FeRnández AlbalAdejo P. (ed.) Los Borbones. Dinastía y ..., p.403; y SANPERE y MIQUEL, S.: Fin de la nación... p. 76. 
celona, contribuyó a levantar más sospechas sobre su pasado. Su hijo Josep Francesc d'Alós i Rius fue asesor directo de la superintendencia, planificando las rentas y el Catastro en Cataluña (1716). De él se decía: «Era sujeto bastantemente sabido en la jurisprudencia y particularmente en la que mira a los derechos del real erario. Es modesto, prudente, versado en la lengua francesa, afable, estudioso, desinteresado, justo, diestro en la formación de consultas y franco en las Audiencias particulares». Muchos catalanes se quejaban de él «como patricio, diciendo que el mérito con que ha conseguido el título de Castilla —marqués del Puerto Nuevo-, gracias a su parentela, estaba teñida de la sangre del Principado». Pero los borbónicos sospechaban de la complicidad de éste con sus compatriotas: «Es el más puntual en asistir a las horas de Audiencia - fue también Oidor y Regente de la Audiencia en Cataluña-, pero tan blando y condescendiente con los ministros y subalternos, que sus permisiones y disimulos, motivan una muy notable inobservancia [...] bien que aquella inobservancia promueve en gran parte la perjudicial repugnancia con que los demás nacionales [los catalanes] tratan y reciben cualquiera nueva providencia, adictos siempre a su idolatrada antigüedad ${ }^{18}$. Otro hijo de Josep d'Alós, Antonio d'Alós i Rius, militar, puede servirnos también de testimonio de esa ambigüedad. Editó la Carta, Instrucciones y relación de servicios (1767), donde relataba de una forma oficialista y proborbónica la Guerra de Sucesión, con la voluntad de contrarrestar ciertos escritos que evocaban la memoria histórica del austracismo catalán durante la Guerra de Sucesión, pero, en cambio, escribió la Breve Noticia de las cinco principales revoluciones que en varias épocas han sucedido en el Principado de Cataluña, que nunca llegó a publicar y que se consideraría incorrecta por apuntar discrepancias borbónicas y describir o reconocer con demasiado detalle la «rebelión» de los catalanes. Ciertamente el «botiflerisme» catalán estuvo dividido (Ametller mucho más extremado que Alós), pero, en cualquier caso, nadie fue tan radical como Macanaz que desbordó en su voluntad uniformista al pragmático Patiño ${ }^{19}$.

\section{MACANAZ Y LA POLÍTICA EUROPEA DE FELIPE V DESPUÉS DE 1714}

Según Belando, a su vez corroborado por Macanaz, la rebelión en Barcelona, después del once de septiembre de 1714, se movilizaría a partir de 1717, a raíz de la llegada desde Cádiz de la Armada prevista para luchar contra el turco. Finalmente no salió del puerto, lo que creó «algunas turbaciones» en la ciudad. Una carta de Grimaldo de ese mismo año justifica la invasión española de Cerdeña ante las cortes europeas, y en especial ante el Papa, porque desde allí, así como des-

18 Mercader Riba, J.: Felip V i Catalunya, Barcelona, 1985, pp. 25, 26, 31-33 y 95-96; Molas RiBALTA, P.: «Las Audiencias borbónicas de la Corona de Aragón. Aportación a su estudio», en Estudis, n. ${ }^{\circ} 5$ (1976), pp. 59-124; PÉREZ SAMPER, M.A..: «La familia Alós, una dinastía catalana al servicio del Estado (s. XVIII)» en Cuadernos de Investigación Histórica, n. ${ }^{\circ}$ 6, (1982), pp. 195-239.

19 Alabrús, R.M.: Cròniques de la Guerra..., pp.26-28. 
de Sicilia y Nápoles — decía-, seguían llegando refuerzos del emperador Carlos VI hacia Cataluña, a pesar de haberse finalizado la guerra ${ }^{20}$.

El irredentismo de Alberoni con la ocupación de Cerdeña (1717) y Sicilia (1718) comportó las declaraciones de guerra contra España y un notable incremento de la «rebelión de los catalanes». En este punto Macanaz critica a Belando por el hecho de haber comentado que en 1718 «el Archiduque y el rey de Inglaterra solicitaron al duque de Orléans —regente de Francia, después de la muerte de Luis XIV— por poner la división entre España y Francia». Macanaz matiza que fue todo lo contrario: «El de Orleáns que quería alzarse con la Francia ganó al de Inglaterra, ofreciéndole mantenerle en el trono que injustamente ocupaba [Jorge I estuvo permanentemente amenazado por los intentos de restitución a favor de la dinastía Estuardo por parte de los 'jacobitas' escoceses e irlandeses] y por su medio ganó al Archiduque a quién ofreció mantenerle en lo usurpado a España y darle la Sicilia por la Cerdeña y que en la Guerra, el Archiduque emplearía sus fuerzas, el de Inglaterra sus escuadras marítimas y el de Orléans les cubriría el gasto a ambos y si necesario fuera haría la Guerra a la España, pero que ellos le ayudarían a él a alzarse con la Francia, pero que para esto era preciso acabar con las fuerzas de mar y tierra de España, que fue lo que en esto hubo ${ }^{21}$.

Desde su estancia en Aragón Macanaz no conectaba con el duque de Orléans, por la participación de aquél en la «trama de Lérida» y los supuestos intentos de envenenamiento de Felipe en 1709 por parte del regente. Ello le llevó a participar en la conspiración del príncipe de Cellamare contra el de Orléans en 1718. Cellamare era sobrino del cardenal Giudice, que se puso al servicio de Felipe $V$ mediante la buena amistad de su tío con el barón de Ripperdá. Otro colaborador destacado en esta conspiración fue Vicente Portocarrero, sobrino del cardenal. Alberoni lo sabía. Media Provenza francesa estaba implicada en la operación. Macanaz relata cómo Felipe V envió una carta a los «Estados de Francia» y cómo éstos «estaban bien dispuestos y que acudieron al embajador de España, Príncipe de Chelamare». Añade: «Que el motivo de las cartas que el Rey Católico envió a los Estados de Francia, cuya dirección pasó por mis manos; estos acudieron luego a mí y ofrecieron sacrificar sus haciendas y vidas para la libertad de su Rey y de su Patria, aquel y esta, sujetos a la tiranía del de Orleáns y que para esto tenían escritas sus cartas al Rey Católico, a quién elegían como verdadero y legítimo sucesor de aquella Corona, por su único protector, cuyas cartas me entregaron y yo las pasé a Chelamare». El pretendido golpe de estado fue descubierto a tiempo por el de Orleáns. Macanaz insinúa que Alberoni lo filtró, pero que también se fue de la lengua el secretario de Cellamare, Triviño.

Lo más interesante es que Macanaz no tenía ningún nombramiento pero actuaba desde su exilio como si fuese un agente secreto en nombre de Felipe V. Des-

20 BNM, Mss 2768, Males ..., fols. 106 y 107; CAMPBELL, J. (ed.): Memoirs of the duke de Ripperda first ambassador from the States-General to his most catholik Majesty, London, 1740, pp. 33-36.

21 BNM, Mss 2768, Males ..., fol. 161; Belando, N.: Historia civil..., vol. III, año 1718, pp. $206-210$. 
de 1717 escribía a Grimaldo cartas, que éste casi nunca leía, quejándose de su precaria situación en Pau de Bearn. Fue este mismo año cuando Felipe $\mathrm{V}$ publicó un edicto a su favor para que se mantuviera en la frontera y no tuviera que presentarse a la Inquisición. ¿Pero puede pensarse en alguna misión secreta de Macanaz en Pau? ¿Por qué estuvo allí casi nueve años y no se le mandó directamente a París? ¿La invasión de Cerdeña se hizo para entretener o «divertir a la Alemania que entonces mantenía la guerra con los turcos», como dice en un momento determinado Macanaz? ¿El verdadero objetivo de Felipe $V$ era distraer del alcance de la conjura en Francia, a cuya corona nunca renunció? Según Kamen el rey padecía un depresión muy fuerte en 1717, por lo que se barajó una posible regencia de Alberoni, avalada por el de Orleáns, que conspiró con algunos grandes de Castilla ${ }^{22}$.

Todo ello precipitó la invasión de España por las tropas francesas. Orleáns envió al ejército francés para «fomentar la rebelión en Cataluña, Fuenterrabía y Puerto de Pasajes» a principos de 1719. Macanaz explica cómo, al cabo de poco, el mariscal Berwick recibió órdenes concretas del regente de dejar San Sebastián y Pasajes y ocupar directamente Cataluña, dado que la «rebelión tendría más fuerza». En octubre tomó la Seu d'Urgell y después Roses, y en noviembre - dice Macanaz- entre los franceses y los «miqueletes catalanes» (19 batallones) acabaran con casi todo si no hubiera sido por los «españoles de Pau». Pero Macanaz ya no se encontraba en Pau. Fue desplazado hábilmente por el de Orleáns a Montalbán y después a París, ante la posibilidad de que pudieran repetirse hechos como los de la conspiración del año anterior. Parece directa la conexión de Pere Joan Barceló (Carrasclet) con los franceses. Castellví le atribuye unos 6.000 guerrilleros, sobre todo en el Camp de Tarragona. Hasta 1721 hubo diferentes alzamientos antiborbónicos en toda la provincia de Tarragona, pero también en las comarcas de l'Alt Empordà, Cerdanya, Ripollés, Garrotxa... Incluso en la Seu d'Urgell, ocupada por los franceses, se proyectó una conjura entre el inglés Stanhope y antiguos austracistas, lo que demuestra la fragilidad de la unidad borbónica peninsular. El objetivo fundamental del regente era evitar la formación de una «monarquía universal» borbónica. La idea era compartida por Inglaterra y Austria en la Cuádruple Alianza, en Cambrai, y se consolidó con la Paz de Viena (1725). Después, lo que hizo cambiar de estrategia a Inglaterra fueron los tratados secretos entre España y Austria que se pactaron a raíz de la Paz general ${ }^{23}$.

22 BNM, Mss 2768, Males ..., fols. 163 y 203; TAXONERA, L.: El duque de Riperdá, el gobernante aventurero, Madrid, 1945, pp. 101-109; KamEN, H.: Felipe V. El rey que reinó dos veces, Madrid, 2000, pp. 155-156.

23 BNM, Mss 2768, Males ..., fols. 168-170; CAstellví, F. de: Narraciones..., vol. IV, pp. 647-674; IGLÉSIES; J.: El guerriller Carrasclet, Barcelona, 1974; MerCAdER RIBA, J.: Els Capitans Generals (segle XVIII), Barcelona, 1980, pp. 63-75; ToRRAs RIBÉ, J.M.: Escrits polítics del s. XVIII. II. Documents de la Catalunya sotmesa, Vic, 1996, pp. 5-35; AlBAREDA SALVADÓ, J.: «Represión y disidencia en la Catalunya borbónica (1714-1725)» en Mestre, A. y GIMÉnEZ, E. (eds.), Disidencias y exilios en la España Moderna, U. de Alicante, 1997, pp. 543-555; Albareda Salvadó, J.:, El «cas dels catalans». La conducta dels aliats arran de la guerra de Successió (1705-1742), Barcelona, 2005, pp. 193-195; ALABRús, R.M.: «Pensamiento político y opinión en Cataluña en el siglo XVIII», Historia Social, n. ${ }^{\circ} 24$ (1996); Alabrús, R.M.: Felip V i l'opinió..., pp. 334-349. 
A pesar del Tratado de España con la Cuádruple Alianza (1720) los disturbios continuaron hasta al menos 1724. Así lo demuestra el edicto del conde de Montemar de ese año prohibiendo las armas y el uso de la pólvora «para asegurar la quietud pública y exterminar los fascinerosos que la perturban en este Principado». Macanaz se manifiesta muy contrario al Tratado y lo encuentra desventajoso para España, puesto que «el rey fue mal aconsejado por el confesor Daubenton -hombre que considera aborrecido por la nación española, tirano, traidor y espía del de Orleáns- para que renunciase a Cerdeña y a los derechos de Francia a favor del duque, a los Países Bajos y a los Estados de Italia a favor del emperador (menos Sicilia que pasaría al duque de Saboya) a cambio de la renuncia de las pretensiones del Carlos VI en las Indias, con la sucesión de Parma y Toscana para los hijos de la Farnesio y Gibraltar para Inglaterra». Considera que todo lo acordado estuvo amañado entre el duque de Orleáns y el marqués de Scotti, enviado de la casa de Parma después de la caída de Alberoni. Macanaz señala también que entre los planes del regente francés estaban las bodas de sus dos hijas con el príncipe de Asturias y el infante Carlos respectivamente, a cambio del matrimonio de la infanta María Victoria con Luis XV de Francia. Coincide con Belando en el hecho de que cuando el de Orleáns consiguió casar a su hija mayor con Luis «aumentó a los oficiales y soldados sueldo y paga y aumentó el número de 19 batallones de miqueletes catalanes revelados que aún se mantenían» y que nunca estuvo realmente por la labor de celebrar el último matrimonio, el del heredero al trono francés con la infanta española. Pero la muerte inesperada del regente en 1723 conllevó la formación de un nuevo gobierno en Francia, a manos del duque de Borbón ${ }^{24}$. Éste, a diferencia del anterior, optó por una vía pacifista y «deshizo los 24 batallones de miqueletes catalanes que el duque de Orleáns dispuso se volviesen a revelar - después de la boda - y los hizo formar y los entretuvo para sus ideas; pero en esta ocasión el Borbón los envió a sus casas». Al mismo tiempo se deshizo el matrimonio de Luis XV con la hija pequeña (de siete años) de Felipe $V$ e Isabel Farnesio con la excusa de la frágil salud del rey y de la necesidad imperativa para Francia de un heredero (Luis XV finalmente se casó con la hija del rey de Polonia). Macanaz sigue responsabilizando de que no se celebrase la boda al de Orleáns y al emperador. Fue miembro de la comitiva que escoltó a la infanta a su vuelta a España y se esperanzó en un hipotético regreso, al que se opuso el marqués de Scotti: «Sabiendo esto el tirano y traidor marqués de Scotti y conociendo que lo que yo tardase en llegar a los pies del rey, tardarían en ser descubiertas a S.M. sus famas, maldades y que acabaría con el y con todos los suyos con tan fuertes como verdaderos temores habló a la reina y la dijo que nadie en el mundo podría serle más perjudicial que yo [Macanaz] al lado del rey y que si yo iba se descubrirían todas las cosas y que si S.M. viese el modo de atajar mi marcha por que de lo contrario la amenazó - a la reina- con irse a Viena». Entonces Isabel de Farnesio escribió a Macanaz y lo engañó, para que no volviese, con una posible representa-

${ }^{24}$ BNM, Msss. 2768, Males ..., fols. 183-185 y 201-209; Martín Gaite, C.: Macanaz... pp. 361-365. 
ción suya del gobierno en las negociaciones de Cambrai. Efectivamente Macanaz volvió a Francia (1724), pero sin ningún nombramiento concreto, aunque se autoproclamaba ministro de España. Al plenipotenciario real español, Berretti-Landi, le daba pena y se lo llevó consigo a Bruselas. A la muerte de éste el español le sustituyó en sus funciones sin el consentimiento de la corte de Madrid. Grimaldo se enfadó mucho con él y lo envió a Lieja. Allí estuvo hasta 1727 y se casó con María Maximiliana Cortés o Courtois, flamenca de origen español. Día a día seguía desencantándose de la política francesa, de Luis XV y de su hombre fuerte ahora, el cardenal Fleury 25 .

Cuando la firma de la Paz de Viena (1725) entre España y Austria se manifestó totalmente contraria a ella. Critica a Belando que "calle deliberadamente» y no «por temor», en esta ocasión, sobre como se gestó, asegurando que Scotti y Ripperdá eran hombres del emperador, a quien le interesaba efectuar «tratados engañosos» con España. Matiza así a Belando: «Firmó Ripperdá porque así se lo mandó el marqués de Scotti y que a este le valió una suma grande de dinero y no menos a Ripperdá quién como traidor [...] vendió el secreto de su ministerio a Ingleses y Holandeses y se empeñó en apartar del servicio a los que en el había y dar los empleos a los que solo por huir de sus delitos se habían pasado a los enemigos». Pero no era el único que se oponía a la Paz de Viena. Grimaldo, que tenía a los grandes a su favor, se opuso a ella encarnizadamente, desprestigiando y tergiversando, en gran medida, la labor de Ripperdá. Los «Patiños», Patiño y su hermano, el marqués de Castelar, también se opusieron a ella, a pesar del pragmatismo que caracterizaba al primero. En parte porque Ripperdá, durante su breve gobierno (desde finales de 1725 hasta mayo de 1726) los había desplazado de sus cargos. Quizás fue este el momento de mayor sintonía de Patiño con los grandes del «partido español». Se perdería progresivamente en la década de 1730, en especial en el período 1735-36, por su labor reformista en la Hacienda y el comercio y por su creciente influencia en el gobierno y ante la reina ${ }^{26}$.

\section{EL REGALISMO DE MACANAZ Y SU FRACASO POLÍTICO}

Hasta la llegada de Felipe V la Santa Sede ejercía mayoritariamente el control sobre las órdenes religiosas y se vinculaba directamente al Santo Oficio a partir de las «reservas pontificias» y la representación del Nuncio. Sin embargo, el carácter

25 BNM, Mss. 2768, Males ..., fols. 313-314 y 318.; MARtín Gaite, C.: Macanaz..., pp. $370-371$ y 377.

26 BNM, Mss. 2768, Males ..., fols. 319 y 323; EGIDO, T.: Opinión pública y oposición al poder en la España del siglo XVIII (1713-1759), Valladolid, 1971; EGIDo, T.: Sátiras políticas de la España Moderna, Madrid, 1973, pp. 48 y 49; AlaBRús, R.M.: «Conversación Curiosa entre Riperdá y Brutto. Un texto fundamental para el conocimiento de la vida de Ripperdá», en Homenaje a D. Antonio Domínguez Ortíz, U. de Granada, (en prensa); AlABRús, R.M.: «Ripperdà: un ex-austriacista dins del règim borbònic» en Miscel.lània Homenatge a Ernest Lluch, (en prensa); MAÑER, S.J. (trad.): Historia del duque de Riperdá, primer ministro de España en el reynado del Sr. Felipe Quinto, Madrid, 1796, p. 213; BELANDo, N.: Historia civil..., vol. III, años 1724 y 1725, pp. 351-352 y 374-391. 
sagrado de los príncipes y el origen divino del poder monárquico —defendidos por Bossuet- eran una justificación perfecta para que la monarquía se entrometiese en la jurisdicción eclesiástica. A lo largo de la Guerra de Sucesión la necesidad económica de la monarquía borbónica aceleró las medidas regalistas. Uno de los primeros ensayos fue el de Macanaz en Xàtiva, a raíz de su nombramiento como Juez de Confiscaciones en Valencia (1707), con un primer intento de desamortización llamando a «todos los eclesiásticos que vivían en Játiva o en sus términos tenían y poseían cualesquiera rentas perpetuas o vitalicias de otros derechos para que dentro de 30 días comparezcan a este Juzgado a justificar fidelidad que haciéndolo se les mandará a sus iglesias o conventos». Obcecado por la infidelidad del clero valenciano (lo creía posicionado a favor de la causa austracista), sugería la penalización de éste. Su regalismo levantó tantas protestas en Valencia que llegó a plantearse su excomunión en 1709 (aunque el tema se minimizó por el transfuguismo de Folch de Cardona al austracismo).

Macanaz, de vuelta a Madrid, a lo largo de 1710, intrigó contra el nombramiento del cardenal italiano Franceso del Giudice (favorito del duque de Medinaceli) como inquisidor general -lo consideraba un extranjero entrometido- tras la muerte del anterior, Antonio lbáñez de la Riva. Parece ser que su objetivo, en estos momentos, era el de iniciar un proceso de desclerización, al unísono con la Orsini, y el beneplácito de la reina María Luisa. Así, previeron que el marqués de Villena, además de condestable del rey, ocupase la plaza vacante del arzobispado de Toledo, cosa que éste rechazó finalmente. La operación se pretendía hacer a espaldas del cardenal del Giudice, al que Macanaz acusaba de austracista y de complicidad con el $\mathrm{Papa}^{27}$.

Tras su no menos controvertida actuación en la Intendencia de Aragón (1711), el proyecto que más problemas le trajo fue el del Pedimento (diciembre de 1713). Según sus propias palabras se inspiraba directamente en los papeles de Juan Chumacero, que le dio el rey y donde se exponían las quejas contra el Nuncio romano por sus abusos durante el reinado de Felipe IV. Parece ser que el «Memorial» regalista del consejero Juan Chumacero y del obispo Pimentel siguió copiándose e imprimiéndose durante la Guerra de Sucesión. Su idea básica era la de que Roma no gravase más a España. Este criterio lo compartieron también en el siglo XVII Francisco Salgado, Melchor Cano en sus «Pareceres» o el cardenal Zapata en su «Papel Político». También el obispo Solís de Lérida en su Discurso sobre los abusos de la corte de Roma (1709) partía de ese criterio, y, según Teófanes Egido, fue una de las principales causas de la ruptura de Felipe V con el Papa Clemente XI y la decantación de Roma por el archiduque. Macanaz confiesa que, ante la gran penuria económica provocada por la guerra y la falta de ingresos de la

27 Cortés Peña, A.L.: «La Iglesia y el cambio dinástico» en Serrano, E. (ed.): Felipe $V$ y su tiempo. Congreso Internacional, Zaragoza, 2004, vol. I, pp. 991-1012; EGIDO, T., «El discurso teologizante del antirregalismo (1709)» en Serrano, E. (ed.): Felipe V y su tiempo..., vol. I, pp. 915-932; Martín Gaite, C.: Macanaz..., p. 117; BNM, Msss. 12173, BacallaR, V., Comentarios de la guerra..., fol. 20. 
Hacienda, se planteó en una sesión de Cortes a Felipe V, en Castilla, la necesidad de solucionar los «males que padece España» y cómo Giudice enterró interesadamente la consulta ${ }^{28}$.

A partir del Tratado de Utrecht y del reconocimiento del nuevo Borbón, el Papa intentó retomar las relaciones con España y envió al Nuncio Pompeyo Aldrobandi, que, en un primer momento, hubo de contentarse con negociar con Felipe $V$ desde París ante los recelos del gobierno español. En el texto que nos sirve de fuente, Macanaz dice que habiendo llegado a la corte, procedente de su intendencia en Aragón, el rey le había confiado el tratar el «Ajuste» en París con la Santa Sede. Argumenta como, de nuevo, el marqués de Mejorada le dio los papeles de Chumacero que Giudice había desestimado, para que los revisase y elaborase y, al mismo tiempo, le nombró «Fiscal General de la Monarquía»(1713). De ahí salieron los 55 artículos del Pedimento fiscal.

Le critica a Belando que omitiese la conducta de Giudice y que no aclarase que Felipe no le retiró de la negociación del «Ajuste» con Aldrobandi en París, sino que él no podía asistir por su nombramiento de Fiscal y que por ello el rey le dio libertad para delegar en quien quisiese la negociación, por lo que se decantó a favor de José Rodriguez de Villalpando, marqués de la Compuesta.

Según el mismo Macanaz, en el referido manuscrito, las mayores reticencias al «Ajuste» las ponía Roma, puesto que la mayor parte del Pedimento pretendía limitar el «ingreso del dinero que se saca de España». Algunos de los principales puntos que se intentaron negociar con el Papa, a lo largo de 1713-1714, fueron el quitar la jurisdicción al Nuncio de España y dejarle tan solo como embajador ordinario del Papa, acatando el Concilio Tridentino, y que fuese Felipe $V$ quien controlase y reglase conjuntamente con él los pleitos eclesiásticos, quedando los delitos graves para el Juez del Breve de Cataluña. Como medida sancionadora al clero por el seguimiento de la causa austracista, se establecería un Juez del Breve como en Cataluña, primero para cuatro o cinco ciudades españolas, y con el tiempo, para toda España, ya que se pretendía que los eclesiásticos que cometiesen algún exceso fuesen reprimidos «según las leyes exemplares y Breves apostólicos y que estuviese el Breve conjuntamente con los Consejos, Chancillerías y Audiencias $u$ otros tribunales regios en sus reinos y dominios y así mismo que su Santidad expediría Breve con amplísimas facultades al Prelado que el rey nombrase para las reformas de las religiones». Además, el marqués de la Compuesta planteó al Nuncio la propuesta de Macanaz, de «que todos los eclesiásticos que turben la jurisdicción real [...] se observase con ellos la práctica del reino de Valencia; que quede la competencia a un Juez de quién no habría apelación posible» y de «que los eclesiásticos concurriesen a los gastos de Guerra [...] pagasen las alcabalas de lo que comercian y también los demás bienes, e igualmente todo

28 EGIDO, T.: «El regalismo y las relaciones iglesia-estado en el siglo XVIII» en Historia de la Iglesia en España, Madrid, 1979, vol. IV, pp. 127-132 y 139-143. 
lo que adquiriesen, cargas, gavelas y demás contribuciones reales [...], habiendo de pagar de todo, como los demás seglares».

Se le planteó también al Papa otorgar potestad a los corregidores sobre las vacantes eclesiásticas y que el rey tuviese «el nombramiento de todos los beneficios reservados, con el fín de darlos a personas idóneas de las Universidades y a otras, y evitar el daño y la equivocación que se experimente en las Provisiones que se hacen en Roma y mayormente no conociendo al sujeto". A cambio, Roma exigía el pago de 8.000 ducados. Finalmente las dos cortes de España y Roma no llegaron a ningún acuerdo y suspendieron las negociaciones. Macanaz se negaba al pago sin un compromiso tácito por parte de la Santa Sede de todo lo anterior ${ }^{29}$.

Macanaz critica a Belando por no haber transcrito en su obra los 55 artículos enteros del Pedimento y por eludir lo mal que se influyó a Felipe en este tema: «Lo mal aconsejaron en lugar de cerrar la puerta de una vez a tantos escándalos y pecados y demás abusos como los más [refiriéndose a los clérigos] deseaban». Le reprocha además que no diga «lo mucho que trabajé en esto» y el «gran número de enemigos que adquirí por ello", así como que no censure a Luis Curiel por su austracismo: «D. Luis Curiel consejero de Castilla, siendo andaluz como hijo de Sevilla que era y no teniendo nada de catalán se declaró a favor de ellos ocultamente, por seguir el partido del archiduque y como veía que yo solo iba venciendo cuantas dificultades se presentaban por el temor ináudito de los catalanes, se declaró acérrimo enemigo mío y dio fomento muchas veces a mi ruina [...]». Se queja amargamente de cómo en este momento la Orsini, el confesor Robinet y el obispo Francisco Solís se desentendieron de él. En lugar de apoyarlo lo denunciaron a Felipe. Pronto el pánico se apoderó del Consejo de Castilla ante sus medidas regalistas, y éste exigió una explicación al Fiscal. Fue entonces cuando Macanaz - dice- elaboró la Respuesta del Fiscal, una explicación sobre la defensa de las regalías, con la finalidad de que sirviera como reflexión o consulta. Pero Curiel, y los cardenales Belluga y Giudice hicieron circular el papel fuera del Consejo. Incluso lo enviaron al Papa «por ser apasionados austríacos», de manera que en febrero de 1714 el inquisidor José Molines (que había obtenido el nombramiento durante la estancia de Giudice en Francia), afecto a Macanaz, escribió una carta desde Roma, diciendo que este papel corría por ahíi ${ }^{30}$.

Mientras el cardenal Giudice en estos momentos estaba en París informando a Luis XIV de los problemas del gobierno español, recomendaba al rey francés la conveniencia urgente del matrimonio de su nieto Felipe $\mathrm{V}$ con Isabel Farnesio, hija del duque de Parma, con buenas relaciones con la iglesia romana. El italiano pensaba así desbancar, definitivamente, los postulados regalistas de la Orsini. Por otra parte, la promoción dentro de España de la Farnesio la llevó a cabo el también italiano Giulio Alberoni (protegido de Vendôme). Es posible que hubiera existido

29 BNM, Mss. 2768, Males ..., fols. 6-9 y 11-24.

30 BNM, Mss. 2768, Males ..., fols. 28-34. 
complicidad entre ambos cardenales, aunque, con el tiempo, los dos personajes se enemistaron. Cuando se le comunicó a Giudice que la Respuesta del Fiscal había llegado a manos de Clemente XI, no tardó en emitir un edicto (agosto 1714), desde Francia, condenando 32 de sus proposiciones y su regalismo, así como las obras de los franceses Barclay (1640) y Talon (1700), y de los españoles Francisco Salgado y Juan de Solórzano entre otros. Macanaz comenta que además de esta condena se añadió «en una quartilla de Papel diez proposiciones que ofendían la piedad de los españoles y la quietud de las religiones». Felipe, enfadado con el inquisidor general, por no haberle consultado antes, le exigió que volviera inmediatamente; pero luego se lo repensó y lo retuvo un tiempo en Bayona exigiéndole explicaciones de su comportamiento. Giudice argumentó que había actuado así a instancias del Consejo de Inquisición. Éste, cuando fue consultado, responsabilizó a Roma. El italiano desde su estancia en Bayona aprovechó bien el tiempo. Macanaz dice que Giudice, a través de sus contactos, consiguió detener en Milán al recién nombrado inquisidor Molines. Luego el propio Giudice se entrevistó con Mariana de Neoburgo (la viuda de Carlos II) y le avisó de que cuando llegase su sobrina, Isabel, para casarse con Felipe, la advirtiese contra la Orsini y contra Macanaz para que «luego que viese al rey, le pidiese lo apartase de su persona». Fue así como Giudice se ganó la confianza de la Farnesio y consiguió volver a España, reintegrándose de nuevo como inquisidor general a partir del decreto del 28 marzo de 1715. También se rehabilitaron a otros como Curiel.

Aunque Macanaz fue cesado como Fiscal del Consejo de Castilla el 7 de febrero de 1715 (el mismo día que Orry), comenta que «ambos se cruzaron por la frontera -refiriéndose a Giudice cuando volvía a España— y que, personalmente, decidió «pedir al rey de irse a Francia, por problemas de salud a tomar aguas de bañera»(Bagnères). Al mismo tiempo afirma que Alberoni había escrito una carta al Papa contra su persona, tildándolo de «mal católico». Giudice y Alberoni en sintonía, no tardaron en facturar al padre Robinet, como Isabel lo había hecho con la Orsini, el mismo día de su llegada, en Jadraque (diciembre de $1714)^{31}$.

Macanaz se despachó contra ellos acusándolos de haber vulnerado las leyes divinas: «Esto era cosa denigrativa a la nación española que llevaba muy mal las novedades de los dos extranjeros [...] La religión de estos dos sátrapas solo les servía a ellos para cubrir con su sagrado nombre las maldades que cometían para quedar árbitros del Gobierno de la Monarquía, sucediendo esto después que el cardenal Giudice estuvo privado de su empleo y exterminado de España, por sus traiciones e irreligión y que restituído como antes estaba, por arte, traza y disposición de Aberoni quién lo hacía para vengarse de aquellos que creían habían tenido parte de su caída, siendo así que él mismo había dado altos motivos para mucho más de lo que se hizo».

${ }^{31}$ BNM, Mss. 2768, Males ..., fols. 38-42 y 52-57. 
Las acusaciones de «mal católico» le llegaron al alma a Macanaz, que se justificó ante Clemente XI con estas cartas: «Deseé se desenterrase el abuso de la Iglesia refugio y cueva de ladrones, facinerosos, homicidas y asesinos en la pasada Guerra [...] y también me persuadí que en esto se hacía al mismo tiempo un gran obsequio a la Santa Sede y un servicio muy especial a Dios, pues se quitaban tantas ocasiones de pecar como la malicia y la codicia y en fin el Demonio han introducido en España [...]. Y en cuantos papeles hice a este fin no tuve otra mira que la del mayor servicio de Dios, buena unión y correspondencia entre las dos cortes; pero cuanto más deseaba esta conclusión, tanto más se embarazó de parte de Roma, por lo que V.S. IIma. sabe y de la de acá porqué después de mis desvelos, los papeles pasaban a otras manos, o más embarazadas o preocupadas de otras ideas, allí se alteraban después de largas dilaciones y se introducían cláusulas muy impertinentes lo que me dio motivo a quejarme al rey, no una vez, sino muchas, y en fin de que yo estuve en París hallé, que uno de estos Papeles adulterados, habiéndose remitido por el rey al Consejo, para que le consultase sobre él, el mes de agosto de 1714, estaba aún sin entregarse en marzo de 1715 [...]. Si hago esta relación a V.S. IIma. con el fin de sincerarme [...] que tuve razón en lo que hice [...] yo solo sé que en la conciencia no me quedó escrúpulo [...] que en la intención que el que por la parte a quién tocase se diesen reglas seguras y ciertas para el servicio de Dios y la quietud de España [...] y para que su Santidad lograse la entera satisfacción de ver a la España con tan buena unión y correspondencia como antes y como ningún otro reino del mundo y que su iglesia como la más obediente a la Santa Sede, la hija primogénita de ella [...] Por esto fui mal hijo de la Iglesia, y por esto se dieron cuantos pasos pudieron inventarse para apartarme de un empleo que no había solicitado y en que estaba con tanta repugnancia como inquietud y de que el Rey mi Amo no habrá olvidado que le pedí algunas veces me permitiera dejarlo»32.

No mucho más tarde (febrero de 1716), desde Pau de Bearn, escribió a Aldrobandi y a Giudice esta declaración de intenciones: «He escrito la Historia de la Religión y de la Iglesia desde la creación del mundo hasta el fin del año 1715 limpiándola de la ideas que en España no conocemos y de que la Santa Sede se ha dado justamente por ofendida en todos tiempos, sin haber contado eso hallado que reforman en lo que yo había escrito [...] Después de esto hallé aquí muy válido un libro hecho por un médico calvinista contra la Inquisición y no solo emprendí el impugnarlo, como lo hice, sino demostrar también como se han condenado los errores y castigado los herejes, desde el origen del Evangelio hasta hoy y como en 25 años que por solicitud de San Luis estuvo establecida la Inquisición en Francia, se vió toda ella limpia de herejías al paso que hoy se ve afligida por ellas [...]. También escribí dos tomos llamados Defensa crítica de la Inquisición contra sus principales enemigos, convenciéndolos y aterrándolos con los mismos escritos que hicieron para infamarla [...] Todo lo cual parece acredita en bastante forma que aún que

32 BNM, Mss. 2768, Males ..., fols. 60-61 y 80-85. 
este Santo Tribunal haya tenido ministros malos y yo me quejé de los que contra toda razón y justicia lo fueron contra mí y otros, no por eso deja de ser el Tribunal más santo, más recto y justificado de cuantos hay y que yo lo conozco, lo declaro y lo defendí siempre así y que por esto no me quejo ni quejaré jamás de él sino de sus ministros desarreglados y aun tiranos [...]». Y añadía que se encontraba bien consigo mismo, ya que ahora «solo tenía que dar cuenta a Dios» y, aunque retirado y dedicado a la lectura, no olvidaba «el concepto que tengo formado de las funestas consecuencias de este Ajuste».

Cuando el Nuncio y el cardenal leyeron la carta se irritaron. No soportaban el carteo constante de Macanaz y menos a Felipe V. A éste último le escribió durante toda su vida. Pero sus cartas no recibían respuesta. Se queja de que eran interceptadas por sus «enemigos» en la corte. Entonces el inquisidor publicó un edicto (junio 1716) convocando a Macanaz para que en el plazo de noventa días se presentara ante el Consejo de la Inquisición por la causa de herejía (influyó una carta de Belluga a Giudice poniéndole al corriente de la ascendencia judía del antiguo Fiscal), apostasía y fuga, al tiempo que se le confiscaban los bienes y se cortaba su correspondencia y comunicación.

Sin duda esta es una de las autoconfesiones más interesantes de Melchor de Macanaz, donde se proclama partidario de la Inquisición y no, como se ha creído a menudo, contrario. Además, buena parte de su regalismo fue una medida política, como se ha visto también en el apartado anterior, por el supuesto austracismo del clero. En realidad chocó con la Santa Sede, siguiendo los precedentes en el regalismo planteado por el obispo Solís y la ruptura consiguiente con España en 1709, como apuntaba Teófanes Egido ${ }^{33}$.

A su exilio de más de cuarenta años contribuyó fundamentalmente el enorme poder de la Santa Sede. De hecho, en sus confesiones, se siente más víctima de una Roma antirregalista que propiamente de la Inquisición española. Es cierto que intentó reformar el Tribunal del Santo Oficio, e incluso desclerizar el Consejo de Inquisición, lo que influyó negativamente hacia su persona. Pero la oposición de los grandes de España, del Consejo de Castilla y de sus adversarios franceses aumentó ante la inflexibilidad de Macanaz. Muchos borbónicos lo responsabilizaban de la estela de la represión llevada a cabo en Valencia y discrepaban de su dogmatismo con el resto de los territorios de la Corona de Aragón.

Macanaz destaca cómo Alberoni criticaba a Giudice ante la Santa Sede y ante Felipe para desacreditarlo y hacer así méritos dada su ambición personal. Por otra parte, Giudice perdió el favor de Isabel de Farnesio, cuando Alberoni le advirtió de que el inquisidor ponía al príncipe Luis en su contra. Giudice no tardó en marcharse a Roma (1716). Se manifestaba pacifista y poco partidario de la intervención en las posesiones italianas. Por fín Alberoni se sintió libre de los arbitristas

${ }^{33}$ BNM, Mss. 2768, Males ..., fols. 86 y 90-91; MARTín Gaite, C.: Macanaz..., pp. 320-321; EGIDo, T.: «El regalismo y las relaciones iglesia-estado...», pp. 142-145. 
franceses, pero también de los simpatizantes del austracismo, como era Giudice, según Macanaz. El próximo objetivo de Alberoni, a corto plazo, era obtener el capelo cardenalicio, para, a su vez, aproximarse y recuperar las buenas relaciones con Roma y conseguir replantear la jurisdicción del emperador Carlos VI sobre los territorios italianos, en especial Parma y Toscana, deseándolos para el infante Carlos casi recién nacido. Ante las reservas iniciales del Papa, Alberoni se negó a que el Nuncio Aldrobandi entrase en España, a menos que Roma le concediese el citado capelo. Así se quedó largo tiempo en Perpiñán. Finalmente, según Macanaz, Alberoni consiguió el capelo del Papa, gracias a las cien mil libras obtenidas de tratos suyos, dudosos - dice Macanaz-, con los ingleses (de hecho, los dos primeros años después de la guerra, se tuvo buenas relaciones con ellos), y a que Felipe y Clemente XI acordaron el «Ajuste» en junio de 1717 sacrificando los derechos y las regalías de la Corona.

A partir del «Ajuste» Alberoni cogió alas e invadió Cerdeña (agosto 1717) y Sicilia al año siguiente. Macanaz explica cómo los hechos se ocultaron al rey, que lo ignoraba «casi todo», resultando así «los males y daños más gravísimos y notables a la España». El irredentismo del cardenal italiano fue condenado rotundamente por el emperador y el Papa. Se llegaron a escribir libelos difamatorios contra Alberoni acusándolo de pretender una alianza con los turcos y de haber financiado la expedición italiana con el dinero del clero, rompiéndose de nuevo las relaciones con Roma ${ }^{34}$.

Aldrobandi promulgó un edicto (junio 1718) por el que tenían que salir todos los españoles que vivían en Roma, bajo la amenaza de pena de confiscación de los bienes que pudiesen tener en España. Por su parte el Papa, presionado por el enorme peso del sector austracista en Roma, anuló los principales puntos conseguidos por Felipe V en el «Ajuste» de 1717: la cruzada, el subsidio y el excusado. La noticia fue recibida con satisfacción por el clero español y difundida por un eufórico Belluga, que no tardó en ser amenazado por Alberoni. De hecho, en 1718, se ordenó a los capitanes generales de la antigua Corona de Aragón que detuviesen a una serie de sospechosos y sediciosos eclesiásticos, sin duda descontentos ante la amenaza del regalismo, que aprovecharon el contexto de la guerra con la Cuádruple Alianza y el distanciamiento del Papa para rebelarse. El cardenal Belluga se vengó mandando las cartas amenazadoras de su rival al Papa, lo que contribuyó al desprestigio del italiano. El decreto de expulsión de Alberoni (1719) lo llevó al confinamiento en Roma. Una vez fue exculpado por la Santa Sede, optó por escaparse hacia los territorios imperiales (él, que significativamente había criticado tanto a Giudice). Según Salvador José Mañer —biógrafo de Ripperdá-, sus con-

34 BNM, Mss. 2768, Males ..., fols. 91-97 y 99-109; EGIDO, T.: «Los hechos y las actitudes inquisitoriales», en La Inquisición en la España borbónica: el declive del Santo Oficio (1700-1808), $H^{a}{ }^{a}$ de la Inquisición en España y América, Madrid, 1984, vol. IV, pp. 1227-1246; GARCíA CÁRCEL, R. y ALABRús, R.M.: «L'exili austriacista. Algunes reflexions», en Josep Fontana. Història i projecte social. Reconeixement a una trajectòria, Barcelona, 2004, pp. 468-478. 
tactos con el cardenal Cienfuegos, parece, les llevó a ambos a la gestación de la Paz de Viena.

Tras la caída de Alberoni se llegó a un nuevo acuerdo con Roma pero sin el pretendido regalismo de Felipe V. Protestas del clero seguía habiendo. A lo largo de 1721 Felipe $V$ propuso un nuevo modelo de reforma eclesiástica, mucho más suave, a través de los concilios y sínodos diocesanos. Incluso el propio Belluga, que tan antiregalista había sido, se dio cuenta de la necesidad de medidas renovadoras en la Iglesia. Gracias a su prestigio en Roma, consiguió que el Papa Inocencio XIII publicara la bula Apostolici Ministerii con la finalidad de que fueran los obispos en sus diócesis quienes tuvieran un control más sistematizado de éstas, aunque sin el patronato real. Sin duda estas medidas descontentaban a Macanaz desde su exilio francés. No fue hasta el Concordato de 1737 con la Santa Sede cuando los obispos obtuvieron una reglamentación mucho más concreta por parte de Roma para evitar las corruptelas ${ }^{35}$.

Por último, Macanaz le reprocha a Belando que no tratase los derechos y las regalías de la corona y que omitiera las cartas de protesta de Felipe $\mathrm{V}$ a Clemente XI después del «Ajuste» de 1717: «Ni me admira ni me espanta el que en esta corte se presente hoy mi templanza con exceso, mi defensa como injuria, mi religión como sacrilegio y como ruina del bien de mis vasallos, como tampoco el que mis adversarios triunfen y sean en ellas celebrados, contemplados y favorecidos, felizmente auspiciados y colmados de gracias y bendiciones apostólicas [...] reconociendo V. Santidad los deplorables e inevitables males que por la falta de pastores se padecen y experimentan cada día las Diócesis vacantes, así en lo que respecta a la disciplina, como en lo que mira a las conciencias, se esfuerza V.E. a persuadirme que deberán imputarse a mis edictos». También le reprocha al cronista alicantino que no tuviera en cuenta «muchos papeles» que responsabilizaban a Alberoni, únicamente, y no al rey, de la "guerra en Italia», y, por último, que no hiciese ninguna mención a la suspensión en junio de 1718 de la cruzada, el subsidio y el excusado.

Lo cierto es que Macanaz, después de la bula de Inocencio XIII y de la Paz de Viena, pasa por una etapa muy depresiva. Ni siquiera hablaba. Solo escribía. Se desengañó de todo y de todos. La muerte de Fleury en 1743 parece que lo revitalizó. Volvió a escribir cartas a Felipe e Isabel. Por fín le llegó, en 1746, un nombramiento del ministro Carvajal para asistir en calidad de representante español al congreso de Breda (para acordar el final de la Guerra de Sucesión austríaca). Su desencanto ante Francia se había deslizado hacia una proanglofília que Carvajal supo muy bien capitalizar. Las recomendaciones que tenía del gobierno español eran de acordar la paz hábilmente con todos y evitar un enfrentamiento con Fran-

35 BNM, Mss. 2768, Males ..., fols. 110-114, 131, 141-146 y 150-152; Alabrús, R.M.: Felip V i l’opinió..., pp. 336-342; MAÑER, S.J.: Historia del duque de Riperdá..., p. 111; MeSTRE, A.: «Religión y cultura en el siglo XVIII», en Historia de la Iglesia en España, Madrid, 1979, vol. IV, pp. 611-617. 
cia, pero él se extralimitó pactando con los ingleses, creyendo, ingenuamente, que éstos estarían dispuestos a retornar Gibraltar y Menorca. El gobierno y algunos grandes, como el duque de Huéscar, criticaron su gestión. Temían que pudiese tener papeles comprometedores, de modo que le obligaron a regresar a España en 1748. Ensenada lo encarceló por motivos políticos. Parece que encima sólo llevaba una de sus obras: Los Daños universales de la monarquía y remedios de ellos. Otros muchos papeles suyos se encontraron en Lieja y se quemaron. Sufrió un calvario en las prisiones de La Coruña y Pamplona en condiciones muy duras (humedades, falta de médico...) para una persona de su edad, que solo aguantó por su fortaleza. Mientras, como dice Carmen Martín Gaite, su proceso inquisitorial seguía adormecido justamente por no haber comparecido ante el Tribunal, todavía en pleno reinado de Fernando VI. En diciembre de 1760, una semana antes de morir, Carlos III, a instancias del marqués de Esquilache, a través de un decreto, dictó su excarcelamiento. La decisión puso en guardia a la Inquisición, pero parece que el propio Ensenada dio el visto bueno ${ }^{36}$. La coyuntura había cambiado desde 1753, con el concordato firmado con la Santa Sede. Tras los fracasos de los «Ajustes» de 1721 y 1737, en el nuevo concordato Benedicto XIV reconocía muchas regalías antes propuestas por Macanaz, Chumacero y Pimentel. Su liberación de la cárcel apuntaba la consolidación del regalismo con Carlos III. El 19 de enero de 1761 la Inquisición suspendió, definitivamente, la causa contra Macanaz, ya después de su muerte.

36 BNM, Mss. 2768, Males ..., fols. 118, 124 y 138; KAMEN, H.: «Melchor de Macanaz and ...», pp. 710-716; Martín Gaite, C.: Macanaz..., pp. 437-439 y 442-452. 